\title{
Comprehensive Screening of Some West and Central African Sesame Genotypes for Drought Resistance Probing by Agromorphological, Physiological, Biochemical and Seed Quality Traits
}

\author{
Komivi Dossa ${ }^{1,2,3, *}$ (D) , Louis W. Yehouessi ${ }^{1}$, Benoît C. Likeng-Li-Ngue ${ }^{4}$, Diaga Diouf ${ }^{3}$, \\ Boshou Liao $^{2}$, Xiurong Zhang ${ }^{2}$, Ndiaga Cissé ${ }^{1, *}$ and Joseph M. Bell ${ }^{4, *}$ \\ 1 Centre d'Etudes Régional pour l'Amélioration de l'Adaptation à la Sécheresse (CERAAS), \\ BP 3320 Route de Khombole, Thiès 21000, Senegal; fridoy@gmail.com \\ 2 Oil Crops Research Institute of the Chinese Academy of Agricultural Sciences, Key Laboratory of Biology \\ and Genetic Improvement of Oil Crops, Ministry of Agriculture, No. 2 Xudong 2nd Road, Wuhan 430062, \\ Hubei, China; lboshou@hotmail.fr (B.L.); zhangxr@oilcrops.cn (X.Z.) \\ 3 Laboratoire Campus de Biotechnologies Végétales, Département de Biologie Végétale, \\ Faculté des Sciences et Techniques, Université Cheikh Anta Diop, BP 5005 Dakar-Fann, Dakar 107000, \\ Senegal; diaga.diouf@ucad.edu.sn \\ 4 Genetics and Plant Breeding Unit, Department of Plant Biology, Faculty of Science, University of Yaounde I, \\ P.O. Box 812, Yaounde, Cameroon; likengbeco@yahoo.fr \\ * Correspondence: dossakomivi@gmail.com (K.D.); ncisse@refer.sn (N.C.); josmarbell@yahoo.fr (J.M.B.); \\ Tel.: +221-773782071 (K.D.); +221-339514993 (N.C.); +237-677702109 (J.M.B.)
}

Received: 27 October 2017; Accepted: 7 December 2017; Published: 11 December 2017

\begin{abstract}
Sesame is an important crop in West and Central Africa playing a role of an alternative cash crop for smallholders. However, sesame productivity is highly impaired by drought. This study aimed at identifying some drought-resistant genotypes and efficient screening traits in large sesame germplasm. Ten genotypes were examined based on 21 biochemical, physiological, agromorphological and seed quality traits under three weeks of water stress. A high variability for drought resistance was observed among the genotypes. The genotypes WC17, WC18 and WC14 were drought resistant, WC12, WC13, WC06 and WC03 were moderately drought resistant while, WC02, WC10 and WC08 were drought sensitive, based on principal component analysis. The resistant genotypes exhibited both avoidance and tolerance features including increase of the root system, reduced water loss, highest activity of antioxidative enzymes and accumulation of proline. They produced higher biomass and had higher ability to maintain seed quality under drought stress compared with the sensitive genotypes. Strong accumulation ( $200 \%$ ratio stress/control) of biochemical markers including superoxide dismutase, ascorbate peroxidase, catalase and proline could be regarded as an important indicator for selecting drought resistant genotypes. This study represents a reference for future research towards developing new varieties with improved drought resistance in West and Central Africa.
\end{abstract}

Keywords: sesame; drought resistance; antioxidant; physiology; seed quality; west and central africa

\section{Introduction}

Sesame (Sesamum indicum L.) is a very ancient crop and often termed as "the queen of oil seeds" because of its high oil quantity and quality [1]. It is grown in nearly all West and some Central African countries with Nigeria and Burkina Faso representing the leading producing countries [2]. Sesame has developed from a crop of marginal importance to a major agricultural export commodity involving several million family-based farmers in this area [3]. In fact, it is progressively adopted 
because its cultivation is relatively simple as it can grow on different types of soil, does not need too much irrigation, is tolerant to high temperatures, not labor-intensive, and fits in well with crop rotation schemes [4,5]. In addition, sesame production demands few investments, which makes it suitable for the small-scale farmers in West and Central Africa. Hence, sesame holds tremendous potential to sustainably improve livelihoods of poor farmers. However, because the crop is mostly grown under rain fed conditions in arid and semi-arid areas of West and Central Africa, it is often subjected to terminal and intermittent droughts [6]. Despite its relative tolerance to drought stress, severe or prolonged drought is detrimental for the productivity by affecting the number of capsules per plant, grain yield and oil yield and quality as well [7-13]. Therefore, identifying drought resistant genotypes is of utmost importance for sesame breeding programs in West and Central Africa [14]. It is difficult to determine an individual indicator for accurately and effectively screen different genotypes for drought resistance as plants have an array of morphological, physiological, biochemical and molecular responses at cellular and whole organism levels, making it a more complex phenomenon [15]. Bänziger and Lafitte [16] reported that secondary traits can help to improve the precision with which drought-resistant genotypes are identified, compared to measuring only grain yield under drought.

Plant-water relations are largely determined by several physiological characteristics including relative water content (RWC) of the leaves wherein drought stressed plants have lower RWC as compared to non-stressed ones [17]. At the biochemical level, water deficit has been observed to stimulate the accumulation of the reactive oxygen species (ROS) such as superoxide $\left(\mathrm{O}_{2}{ }^{-}\right)$, hydrogen peroxide $\left(\mathrm{H}_{2} \mathrm{O}_{2}\right)$ and the hydroxyl radical (- $\mathrm{OH}$ in the leaf, all of which damage the cell constituents [18], leading to leaf chlorosis and senescence [19]. To prevent or alleviate injuries from ROS, plants have evolved an antioxidant defense system that includes non-enzymatic compounds like ascorbate, gluthatione, tocopherol, carotenoids, flavonoids and enzymes such as superoxide dismutase (SOD), catalase (CAT), peroxidase (POX), ascorbate peroxidase (APX), gluthatione reductase (GR) and polyphenol oxidase (PPO) $[20,21]$. In addition, under severe water stress conditions, plant growth is affected and the plant cells accumulate a range of osmotically active molecules/ions including soluble sugars, sugar alcohols, proline, glycine betaine, organic acids, calcium, potassium, chloride ions, etc. Among these compatible solutes, proline plays a major role in osmotic adjustment and also protects the cells by scavenging ROS [22,23].

Sesame germplasm from West and Central Africa are poorly characterized. However, the available genetic diversity in these materials could be deployed for further germplasm enhancement [24]. In this study, we collected genetically diverse sesame genotypes from seven producing countries in West and Central Africa [24] and screened them for drought resistance. Our aim was to determine highly drought resistant genotypes for future breeding and genetic studies and detect some important traits for efficient and rapid screening in large germplasm.

\section{Results}

\subsection{Overall Variability among Genotypes, Water Regimes and Studied Traits}

All the studied traits (Table 1 ) varied significantly among the ten genotypes $(G)$ except for the number of seeds per capsule $(\mathrm{Gr})$ at $p \leq 0.05$. Similarly, highly significant effects of water regimes $(\mathrm{T})$ could be observed for all traits except for Gr. Significant effects of the interaction $G \times T$ were noted for all traits except for Gr, the root volume (VR) and the root dry weight (PSR) at $p \leq 0.05$ (Table 2).

Concerning the seed quality traits, statistical analysis showed that they varied significantly within genotypes $(p \leq 0.001)$. Furthermore, drought treatment has significantly affected all seed components except protein and sesamolin contents (Table 3). Effects of the interaction $\mathrm{G} \times \mathrm{T}$ were also significant for all seed components $(p \leq 0.001)$. 
Table 1. Abbreviations, Definitions and Units of the Studied Parameters.

\begin{tabular}{ccc}
\hline Abbreviation & Definition & Unit \\
\hline RWC & Relative water content & $\%$ \\
LWI & Leaf wilting index & - \\
Gr & Number of seeds per capsule & - \\
HP & Stem height & $\mathrm{cm}$ \\
NC & Number of capsules & - \\
VR & Root volume & $\mathrm{cm}^{3}$ \\
LR & Primary root length & $\mathrm{cm}$ \\
PFR & Root fresh weight & $\mathrm{g}$ \\
PSR & Root dry weight & $\mathrm{g}$ \\
PFT & Stem fresh weight & $\mathrm{g}$ \\
PST & Stem dry weight & $\mathrm{g}$ \\
SOD & Superoxide dismutase & $\left(\mathrm{U} \cdot \mathrm{g}^{-1} \cdot \mathrm{min}^{-1}\right)$ \\
CAT & Catalase & $\left(\mathrm{U} \cdot \mathrm{g}^{-1} \cdot \mathrm{min}^{-1}\right)$ \\
APX & Ascorbate peroxidase & $\left(\mathrm{Ug} \cdot \mathrm{min}^{-1}\right)$ \\
Pr & Proline content & $\left(\mu \mathrm{g} \cdot \mathrm{g}^{-1} \cdot \mathrm{Fw}^{\mathrm{w}}\right)$ \\
LAC & Linoleic acid content of the seed & $\%$ \\
OC & Oil content of the seed & $\%$ \\
OAC & Oleic acid content of the seed & $\%$ \\
PC & Protein content of seed & $\%$ \\
SC & Sesamolin content of the seed & $\%$ \\
SeC & Sesamin content seed & - \\
R/S & Root to Shoot ratio & $\%$ \\
& & $\%$ \\
\hline
\end{tabular}

Table 2. Effects of Drought Treatment on Morphological, Physiological and Biochemical Traits of Ten Sesame Genotypes.

\begin{tabular}{cccccccccccccccc}
\hline SV & $d f$ & RWC & Gr & VR & LR & PFR & PFT & NC & PST & PSR & HP & SOD & CAT & APX & Pr \\
\hline G & 9 & $*$ & ns & $* * *$ & $* * *$ & $* * *$ & $* * *$ & $* *$ & $* * *$ & $* *$ & $* * *$ & $*$ & $* * *$ & $* * *$ & $* *$ \\
T & 1 & - & ns & $* *$ & $* *$ & $* *$ & $* * *$ & $* *$ & $* * *$ & $*$ & $* * *$ & $*$ & $* *$ & $*$ & $* *$ \\
$\mathrm{G} \times \mathrm{T}$ & 9 & - & ns & ns & $* * *$ & $*$ & $*$ & $* *$ & $* *$ & ns & $* *$ & $*$ & $*$ & $* *$ & $*$ \\
\hline
\end{tabular}

* Significant at $p \leq 0.05 ;{ }^{* *}$ Significant at $p \leq 0.01 ;{ }^{* * *}$ Significant at $p \leq 0.001 ;$ ns, Non significant at $p \leq 0.05$;

$\mathrm{G}=$ Genotypes; $\mathrm{T}=$ Treatments; $\mathrm{G} \times \mathrm{T}=$ Interaction Genotypes and Treatments.

Table 3. Effects of Drought Treatment on Seed Quality Traits of Five Sesame Genotypes.

\begin{tabular}{cccccccc}
\hline SV & $d f$ & OAC & LAC & OC & PC & SeC & SC \\
\hline $\mathrm{G}$ & 4 & $* * *$ & $* * *$ & $* * *$ & $* * *$ & $* * *$ & $* * *$ \\
$\mathrm{~T}$ & 1 & $* * *$ & $* * *$ & $* * *$ & $\mathrm{~ns}$ & $* * *$ & $\mathrm{~ns}$ \\
$\mathrm{G} \times \mathrm{T}$ & 4 & $* * *$ & $* * *$ & $* * *$ & $* * *$ & $* * *$ & $* * *$ \\
\hline
\end{tabular}

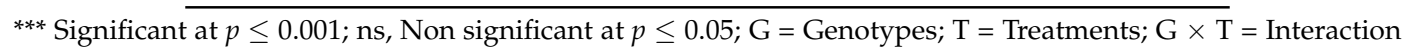
Genotypes and Treatments.

\subsection{Effects of Water Deficit on Sesame Plant Growth and Yield Relative Indexes}

When subjected to drought stress, sesame genotypes responded differently. As shown by the leaf wilting index (LWI) of the ten genotypes, WC08 displayed the lowest wilting signs followed by WC17 and WC18 during the three days of data recording. WC02 was the most affected genotype. Overall, wilting signs increased with duration of water stress (Figure 1A). Regarding the relative number of capsules (rNC), the genotype WC14 displayed the highest value while WC08 displayed the lowest value meaning that water stress did not affect capsule formation in WC14 contrary to WC08. More interestingly, WC14 had produced more capsules under water deficit condition as compared with the control plants (Figure 1B). Although there is no significant effect of water deficit on the number of seeds per capsule (Gr), when we observed the relative value $(\mathrm{rGr})$, the seed set was more affected in WC06 and WC14 by drought compared to the remaining genotypes (Figure 1C). 

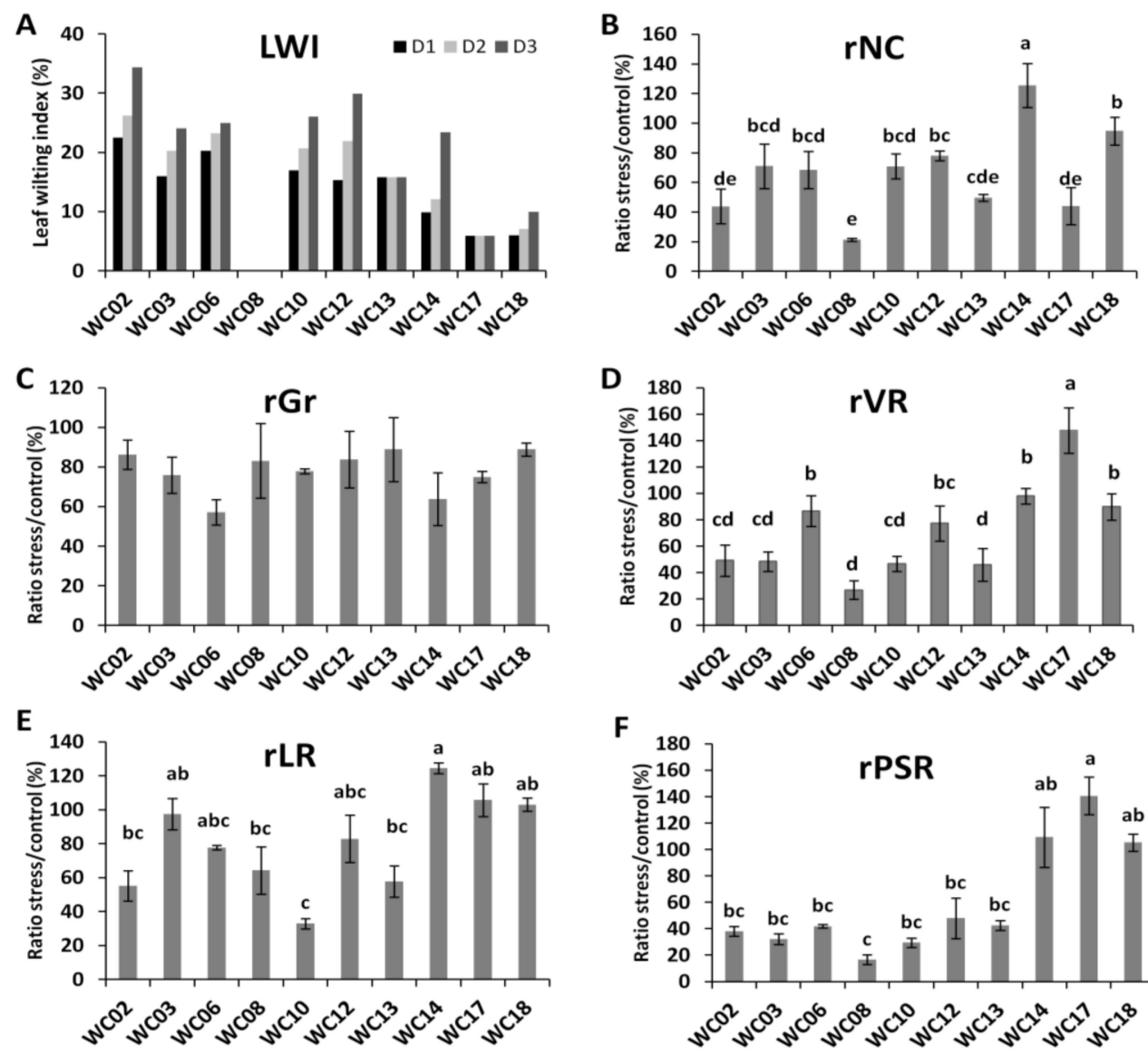

F
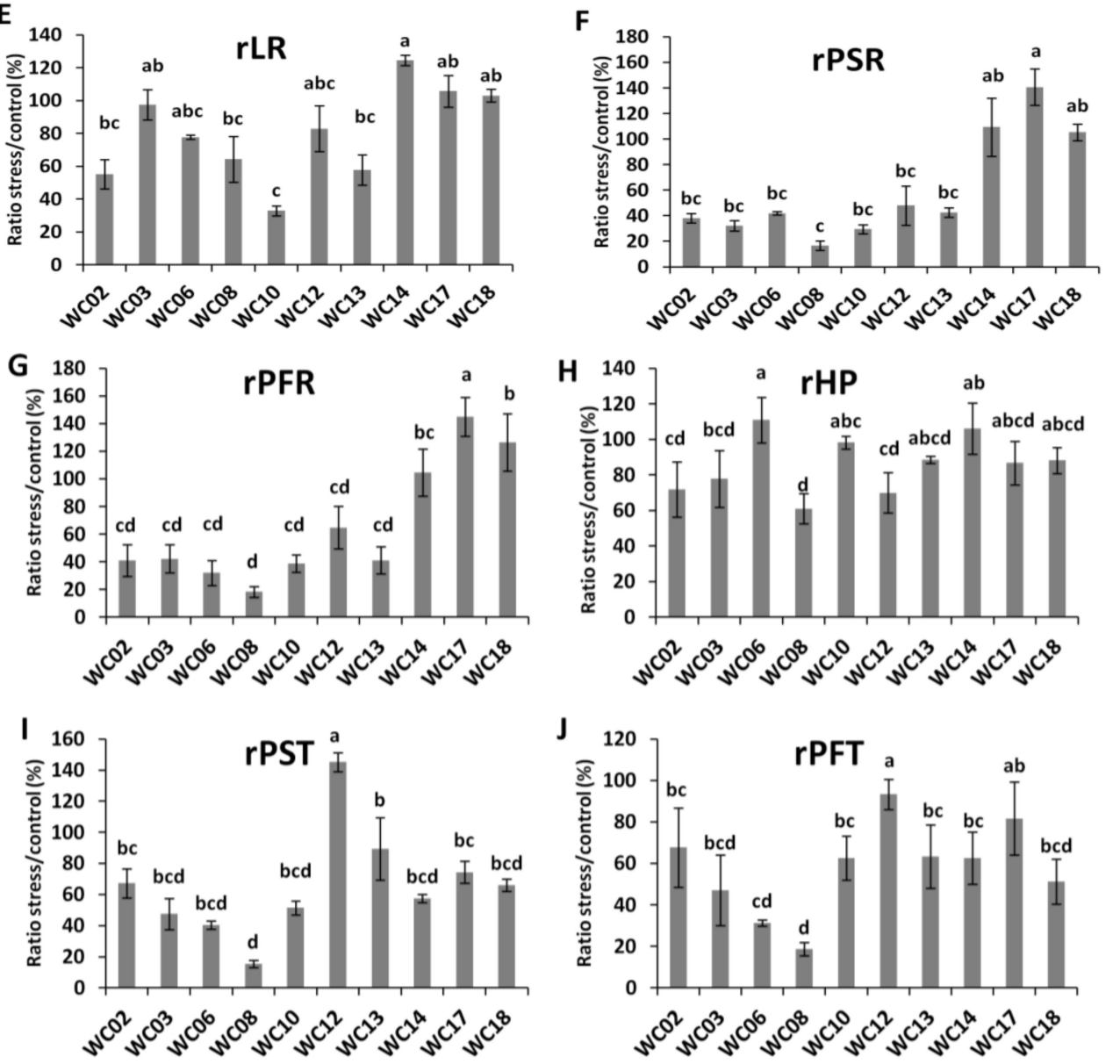

Figure 1. Effects of water deficit on sesame plant growth and yield relative indexes. (A) leaf wilting index (LWI); (B) relative number of capsules $(\mathrm{rCN})$; $(\mathbf{C})$ relative number of seeds per capsule $(\mathrm{rGr})$; (D) relative root volume (rVR); (E) relative primary root length $(\mathrm{rLR})$; (F) relative root dry weight (rPSR); (G) relative root fresh weight (rPFR); (H) plant height (rHP); (I) relative stem dry weight (rPST); (J) relative fresh weight (rPFT). Different letters above bars represent significant difference $(p<0.05)$ between genotypes. D1, D2, D3 represent the three consecutive days of LWI recording. 
Drought has significantly decreased the root volume of many genotypes as shown by rVR values. However, the genotype WC17 displayed an increase of root volume under drought stress $(140 \%)$ and the root growth of the genotypes WC18, WC12, WC14 and WC06 were the least affected by drought (Figure 1D). Similarly, drought reduced the primary root length (rLR) of seven out of the ten genotypes. The three genotypes WC14, WC17 and WC18 increased LR under drought stress as compared to the control condition. In contrast, WC10 was the most affected by drought for this trait (Figure 1E). Concerning the relative values of root dry weight (rPSR) and the root fresh weight (rPFR), results showed that the genotypes WC14, WC17 and WC18 increased the root system under drought stress while the genotype WC08 was the most affected for these traits under stress conditions (Figure 1F,G).

The Figure $1 \mathrm{H}$ presents the relative values of the plant height (rHP) across the ten genotypes. WC06 and WC14 had improved shoot height under stress as shown by the rHP values above $100 \%$. In opposite, the shoot development was more significantly reduced in the genotypes WC08 and WC12. The effects of drought stress on the stem dry (rPST) and fresh (rPFT) weights are shown in Figure 1I,J, respectively. The stressed plants of the genotype WC12 have produced more stem biomass under water deficit compared to control plants. Similarly as for rHP, the genotype WC08 was the most affected for stem biomass production under water deficit conditions.

Change in the Root to Shoot $(\mathrm{R} / \mathrm{S})$ ratio is a mechanism of drought responses in plants. As shown in Table 4, five genotypes including WC02, WC03, WC10, WC12 and WC13 displayed a decreased R/S ratio under drought stress. In contrast, the genotypes WC14, WC17 and WC18 considerably increased the R/S ratio under stress. The R/S ratio was not obviously influenced in the genotypes WC06 and WC08 under stress conditions (Table 4).

Table 4. Root to Shoot Ratio (R/S) of the Ten Genotypes Under Normal and Water Deficit Conditions.

\begin{tabular}{ccc}
\hline & \multicolumn{2}{c}{ R/S } \\
\hline Genotypes & Control & Stress \\
\hline WC02 & $0.19 \pm 0.00^{\mathrm{abcd}}$ & $0.11 \pm 0.00^{\mathrm{bc}}$ \\
WC03 & $0.20 \pm 0.00^{\mathrm{abcd}}$ & $0.12 \pm 0.01^{\mathrm{bc}}$ \\
WC06 & $0.148 \pm 0.001^{\mathrm{bcd}}$ & $0.15 \pm 0.02^{\mathrm{abc}}$ \\
WC08 & $0.23 \pm 0.04^{\mathrm{abcd}}$ & $0.24 \pm 0.01^{\mathrm{ab}}$ \\
WC10 & $0.29 \pm 0.06^{\mathrm{abcd}}$ & $0.16 \pm 0.04^{\mathrm{abc}}$ \\
WC18 & $0.08 \pm 0.00^{\mathrm{cd}}$ & $0.23 \pm 0.02^{\mathrm{abc}}$ \\
WC13 & $0.33 \pm 0.04^{\mathrm{a}}$ & $0.17 \pm 0.02^{\mathrm{abc}}$ \\
WC14 & $0.06 \pm 0.04^{\mathrm{ad}}$ & $0.25 \pm 0.03^{\mathrm{abc}}$ \\
WC17 & $0.15 \pm 0.02^{\mathrm{bcd}}$ & $0.28 \pm 0.04^{\mathrm{a}}$ \\
WC12 & $0.16 \pm 0.03^{\mathrm{bcd}}$ & $0.09 \pm 0.00^{\mathrm{c}}$ \\
\hline
\end{tabular}

Different letters $(\mathrm{a}, \mathrm{b}, \mathrm{c}, \mathrm{d})$ represent significant difference $(p<0.05)$ between genotypes.

\subsection{Physiological and Biochemical Responses of Sesame Genotypes to Water Deficit}

The values of the leaf relative water content (RWC) after stress treatment are presented in Figure 2A. The genotypes WC14 and WC17 had more than 80\% RWC after 3 weeks of water stress suggesting their strong drought resistance. In contrast, the genotype WC02 was severely desiccated with dying leaves.

The activities of three antioxidative enzymes including APX, CAT and SOD were measured after drought treatment in the ten genotypes. For SOD, all genotypes showed an increased level of the enzyme activity. The strongest increase of SOD activity level was exhibited by the genotype WC17 (Figure 2B). A similar trend was observed for the APX and CAT activity levels in all the studied genotypes under drought (Figure $2 \mathrm{C}, \mathrm{D}$ ). The APX and CAT activity was most striking in the genotype WC14 and WC18 compared to the remaining genotypes.

The level of proline content in the leaves was also assayed after drought treatment in both conditions and the relative values among the genotypes are presented in Figure 2E. Results showed that 
drought has induced high accumulation of proline in the leaves of all sesame genotypes. The genotype WC06 showed the highest accumulation of proline in the leaves under stress, followed by the genotypes WC14, WC17 and WC18 whereas the genotypes WC03, WC08, WC10, WC01 and WC13 had the lowest proline content.

A

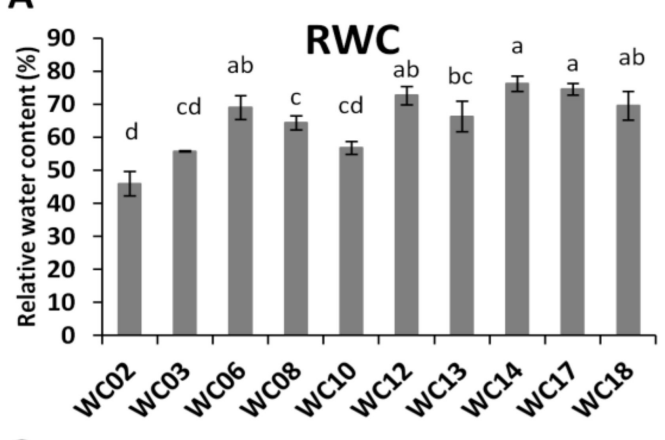

C

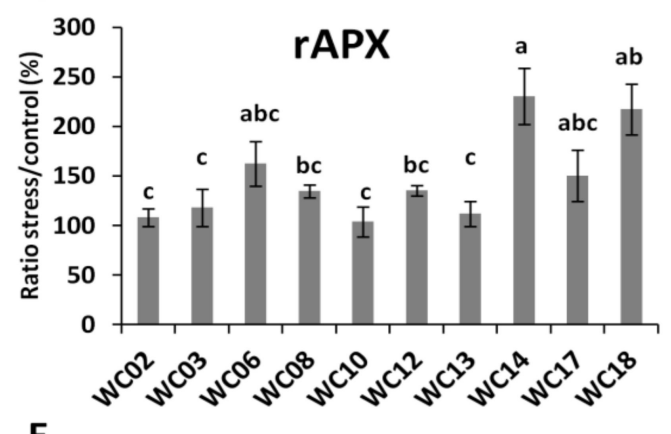

E

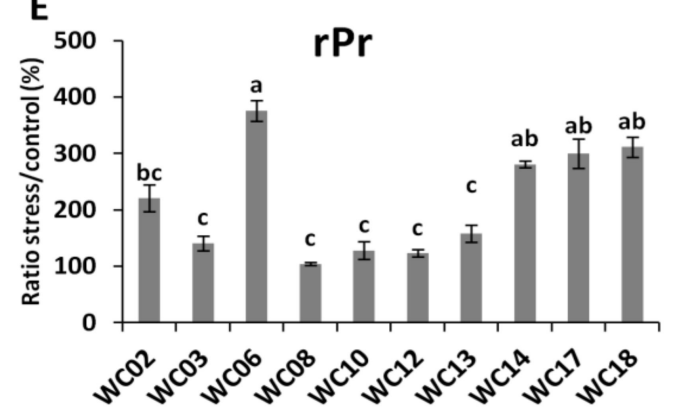

B

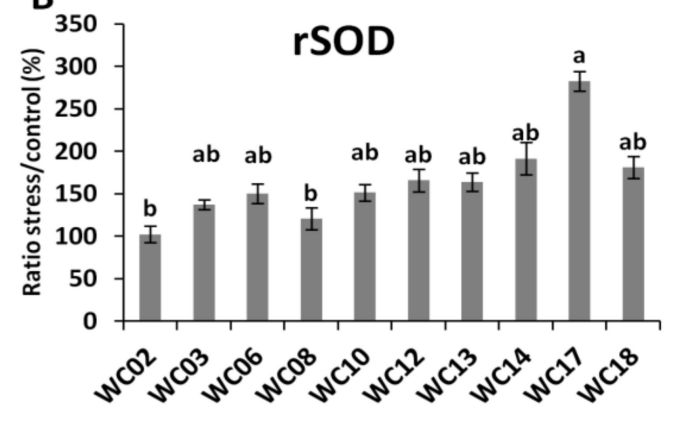

D

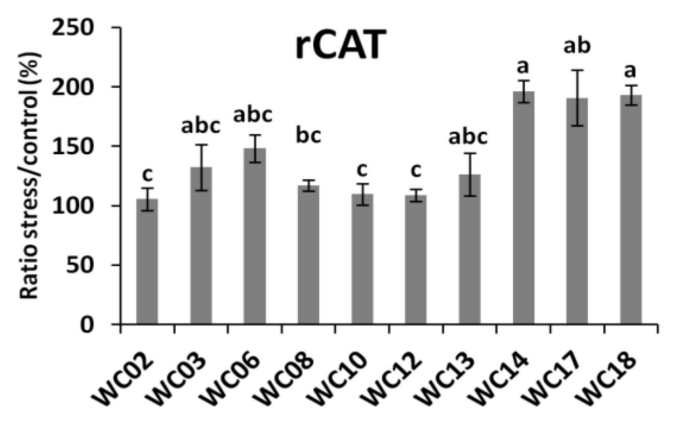

Figure 2. Effects of water deficit on physiological and biochemical traits in sesame genotypes. (A) relative water content (RWC); (B) relative SOD activity (rSOD); (C) relative APX activity (rAPX); (D) relative CAT activity (rCAT); (E) relative proline content $(\mathrm{rPr})$. Different letters $(\mathrm{a}, \mathrm{b}, \mathrm{c}, \mathrm{d})$ above bars represent significant difference $(p<0.05)$ between genotypes.

\subsection{Relationships among the Studied Traits}

A high correlation was observed within the different root traits, antioxidative enzyme activities and morphological traits. In addition, correlation between root traits including VR, PFR, PSR, LR and the biochemical markers SOD, CAT, APX and Pr was positively strong and significant. Moreover, RWC is highly, significantly and positively correlated with root traits such as LR and PSR as well as, the activities of the three enzymes. This implies that both root maintenance/development and strong enzymatic activity under water deficit may help sesame plants to keep good water content in above tissues for stress endurance. Within the 15 traits, only LWI did not display a strong association with any other trait (Table 5). 
Table 5. Pearson correlation (r) between the studied traits.

\begin{tabular}{|c|c|c|c|c|c|c|c|c|c|c|c|c|c|c|c|}
\hline & rVR & rLR & rPFR & rPFT & rNC & rPST & rPSR & rHP & RWC & rSOD & rAPX & rCAT & $\mathrm{rPr}$ & LWI & rGr \\
\hline $\mathrm{rVR}$ & 1 & & & & & & & & & & & & & & \\
\hline rLR & 0.34 & 1 & & & & & & & & & & & & & \\
\hline rPFR & $0.88^{* * *}$ & 0.46 & 1 & & & & & & & & & & & & \\
\hline rPFT & 0.41 & 0.22 & 0.59 * & 1 & & & & & & & & & & & \\
\hline $\mathrm{rNC}$ & -0.03 & 0.67 * & 0.14 & 0.24 & 1 & & & & & & & & & & \\
\hline rPST & 0.38 & 0.08 & 0.43 & $0.86^{* * *}$ & -0.03 & 1 & & & & & & & & & \\
\hline rPSR & $0.76^{* *}$ & $0.64 *$ & 0.90 * & 0.42 & 0.45 & 0.21 & 1 & & & & & & & & \\
\hline rHP & 0.24 & 0.21 & 0.11 & 0.27 & $0.58^{*}$ & 0.10 & 0.24 & 1 & & & & & & & \\
\hline RWC & 0.49 & $0.60 *$ & 0.50 & 0.02 & 0.43 & -0.01 & $0.69^{*}$ & 0.35 & 1 & & & & & & \\
\hline rSOD & $0.83^{* *}$ & 0.45 & $0.92^{* * *}$ & 0.44 & 0.21 & 0.27 & $0.89^{* * *}$ & 0.33 & 0.71 * & 1 & & & & & \\
\hline rAPX & 0.29 & 0.81 ** & 0.37 & 0.38 & 0.75 * & 0.22 & 0.57 & 0.45 & 0.66 * & 0.4 & 1 & & & & \\
\hline rCAT & 0.58 * & 0.79 ** & 0.68 * & 0.60 * & 0.56 & 0.38 & 0.74 * & 0.51 & 0.66 * & 0.73 * & $0.85^{* *}$ & 1 & & & \\
\hline $\mathrm{rPr}$ & 0.62 * & 0.48 & 0.44 & 0.44 & 0.34 & 0.35 & 0.48 & 0.66 * & 0.39 & 0.44 & 0.65 * & 0.74 * & 1 & & \\
\hline LWI & -0.19 & -0.26 & -0.34 & -0.17 & 0.15 & -0.14 & -0.25 & 0.23 & -0.48 & -0.42 & -0.36 & -0.46 & -0.02 & 1 & \\
\hline $\mathrm{rGr}$ & -0.21 & -0.26 & 0.09 & 0.31 & -0.32 & 0.44 & -0.09 & 0.42 * & -0.30 & -0.12 & -0.31 & -0.29 & -0.60 * & -0.22 & 1 \\
\hline
\end{tabular}




\subsection{Drought Resistance Ranking of the Ten Sesame Genotypes Using Integrated PCA Score Values}

Principal component analysis (PCA) was performed based on the relative values of 14 morphological, physiological and biochemical traits investigated in this study to discriminate the ten genotypes according to their drought resistance (the Gr trait was excluded because it did not vary significantly between genotypes and treatments). The first three principal components (PC) or axes explain $78.56 \%$ of the total variance in response to drought treatment $(50.33 \%, 15.71 \%$ and $12.52 \%$ for PC1, PC2 and PC3, respectively). The ten genotypes were grouped into three main clusters (I, II and III). The cluster I gathered together the genotypes WC02, WC08 and WC10. The cluster II encompassed the genotypes WC03, WC06, WC12 and WC13 whereas, the cluster III was composed of three genotypes namely WC14, WC17 and WC18 (Figure 3). Based on the contribution of each trait to the first three axes, we developed the following PCA formulas:

$$
\begin{gathered}
\mathrm{PC} 1=0.28 \times \mathrm{rVR}+0.27 \times \mathrm{rLR}+0.31 \times \mathrm{rPFR}+0.22 \times \mathrm{rPFT}+0.20 \times \mathrm{rNC}+0.15 \times \mathrm{rPST} \\
+0.33 \times \mathrm{rPSR}+0.18 \times \mathrm{rHP}+0.28 \times \mathrm{RWC}+(-0.14) \times \mathrm{LWI}+0.32 \times \mathrm{rOD}+0.3 \times \mathrm{rAPX} \\
+0.35 \times \mathrm{rCAT}+0.27 \times \mathrm{rPr} ; \\
\mathrm{PC} 2=0.31 \times \mathrm{rVR}+(-0.26) \times \mathrm{rLR}+0.32 \times \mathrm{rPFR}+0.34 \times \mathrm{rPFT}+(-0.5) \times \mathrm{rNC} \\
+0.33 \times \mathrm{rPST}+0.08 \times \mathrm{rPSR}+(-0.32) \times \mathrm{rHP}+(-0.13) \times \mathrm{RWC}+(-0.19) \times \mathrm{LWI}+ \\
0.21 \times \mathrm{rSOD}+(-0.31) \times \mathrm{rAPX}+(-0.07) \times \mathrm{rCAT}+(-0.1) \times \mathrm{rPr} ; \\
\mathrm{PC} 3=(-0.03) \times \mathrm{rVR}+(-0.15) \times \mathrm{rLR}+(-0.08) \times \mathrm{rPFR}+(0.46) \times \mathrm{rPFT}+0.1 \times \mathrm{rNC} \\
+0.45 \times \mathrm{rPST}+(-0.16) \times \mathrm{rPSR}+0.33 \times \mathrm{rHP}+(-0.37) \times \mathrm{RWC}+0.39 \times \mathrm{LWI}+ \\
\quad(-0.17) \times \mathrm{rSOD}+0.002 \times \mathrm{rAPX}+0.03 \times \mathrm{rCAT}+0.29 \times \mathrm{rPr} .
\end{gathered}
$$

In addition, a PCA score value for each genotype was calculated using a separate formula:

$$
\text { PCA score value }=(50.33 \% \times \text { PC } 1)+(15.71 \% \times \text { PC2 })+(12.52 \% \times \text { PC } 3)
$$

The ten sesame genotypes were then ranked for drought tolerance based on the PCA score values (Table 6). The genotypes WC17, WC18 and WC14 (cluster III) had the highest PCA score values, suggesting that they were highly drought resistant. In contrast, WC08, WC10 and WC02 (cluster I) displayed the lowest scores and then were found to be the most sensitive genotypes within the germplasm. The genotypes WC03, WC06, WC12 and WC13 (cluster II) showed intermediate values suggesting that they were moderately resistant to drought.

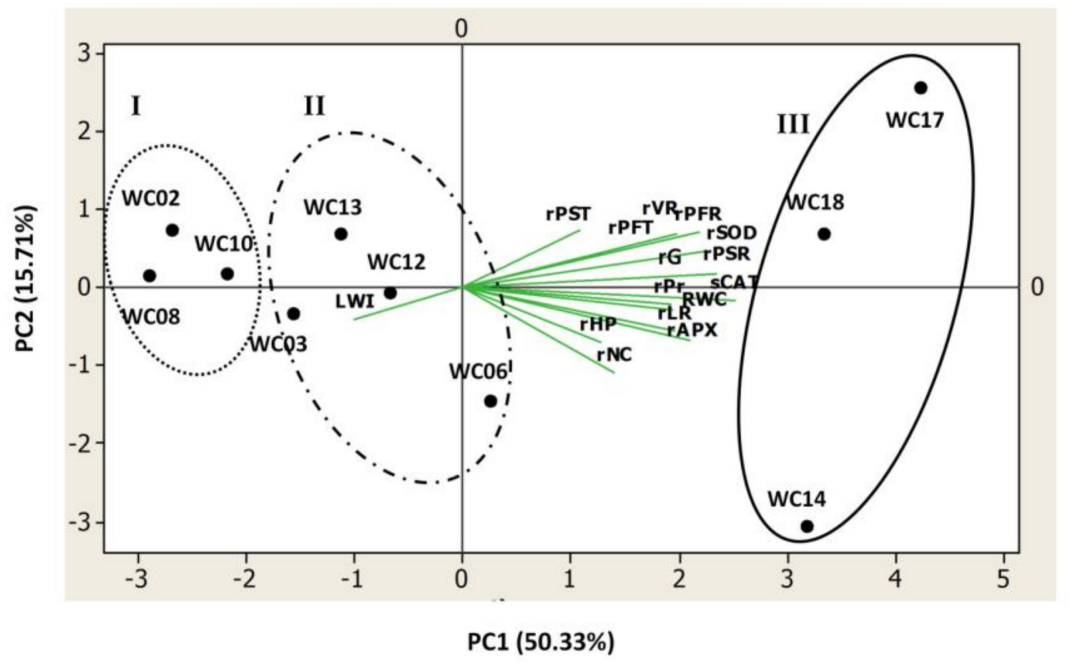

Figure 3. Loading plot obtained from principal component analysis (PCA) carried out based on 14 morphological, physiological and biochemical traits. Percentages in brackets correspond to the explained variances of corresponding components or axes. The circles represent the different clusters. 
Table 6. PCA Ranking Values of the Agromorphological, Biochemical and Physiological Traits of Sesame Genotypes.

\begin{tabular}{cccccc}
\hline Genotype & PC1 & PC2 & PC3 & Score & Rank \\
\hline WC17 & 520.24 & 30.87 & -45.51 & 260.98 & 1 \\
WC18 & 486.53 & -51.59 & -11.69 & 235.30 & 2 \\
WC14 & 475.46 & -172.23 & 27.02 & 215.63 & 3 \\
WC06 & 386.70 & -110.12 & -13.49 & 175.63 & 4 \\
WC12 & 318.26 & -55.67 & 5.80 & 152.16 & 5 \\
WC13 & 301.99 & -30.62 & -21.89 & 144.43 & 6 \\
WC03 & 290.14 & -28.12 & -2.64 & 141.27 & 7 \\
WC02 & 275.09 & -43.21 & -5.38 & 130.99 & 8 \\
WC10 & 266.28 & -47.73 & -19.17 & 124.12 & 9 \\
WC08 & 227.45 & -66.97 & -38.21 & 99.17 & 10 \\
\hline
\end{tabular}

\subsection{Seed Quality Traits under Well-Watered and Drought Stress Conditions in Five Sesame Genotypes}

To uncover the effects of water deficit on sesame seed quality, we measured and compared the oil, protein, sesamin, sesaminol, oleic acid and linoleic acid contents of control and stressed seeds. Only five genotypes yielded enough seeds required for this analysis. Results revealed that drought stress reduced significantly oil and oleic acid contents in the seeds. In contrast, it was observed a significant increase of sesamin and linoleic acid contents in the stressed seeds compared with the control seeds (Figure 4A). Sesamolin and protein contents were not significantly affected by drought stress.

To identify the genotypes with best ability to conserve the seed quality under drought stress, the heatmap-based hierarchical clustering method was used to sort all genotypes using the ratio stress/control (Figure 4B). The seed quality was markedly affected in the genotypes WC02 and WC08 under water stress. In contrast, the genotypes WC14, WC17 and WC06 have well conserved the seed quality under drought stress. Interestingly, the genotype WC06 had higher sesamin, sesaminol and oleic acid contents in seed under drought stress than in control condition.
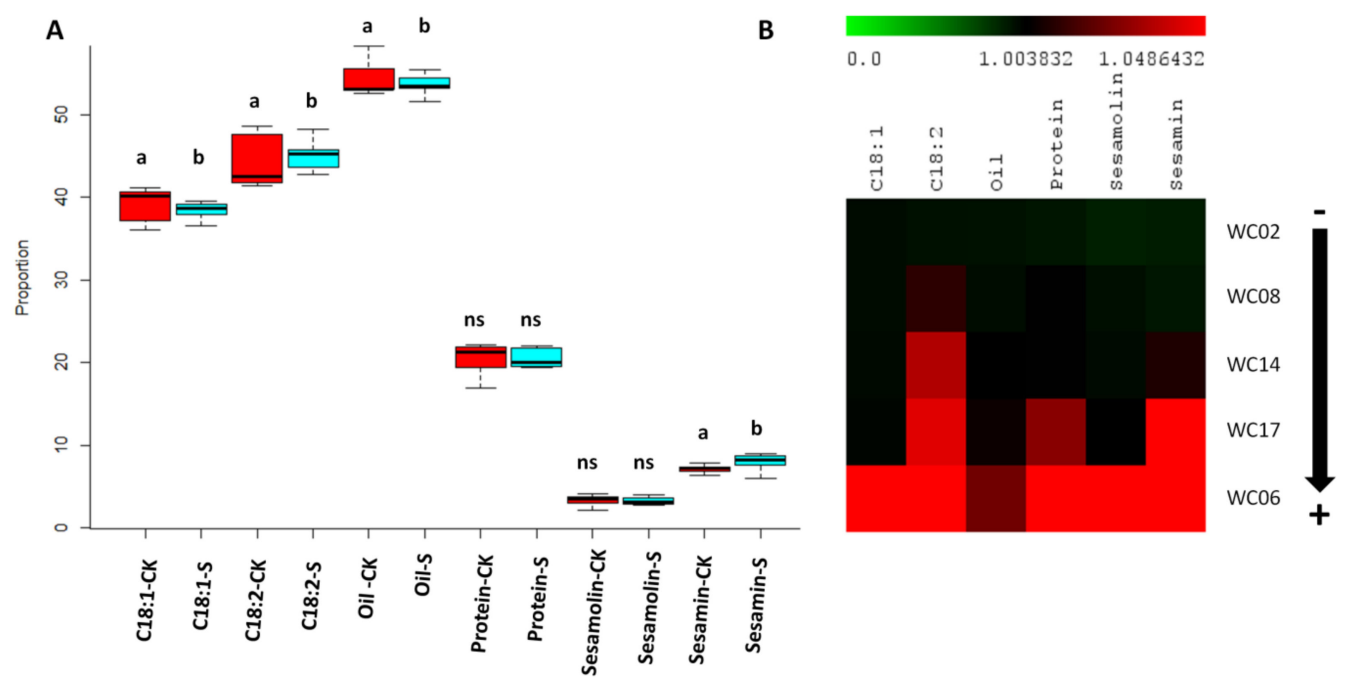

Figure 4. Effects of water deficit on seed quality traits in five sesame genotypes. (A) Boxplot comparing values of seed quality traits under well-watered and stress conditions. Boxes in red color are for control samples while boxes in blue color are for stressed samples; (B) heatmap and hierarchical sorting of the relative values. Different letters $(\mathrm{a}, \mathrm{b})$ above bars represent significant difference $(p<0.05)$ between genotypes. "ns" means no significant $(p<0.05)$. 


\section{Discussion}

Understanding drought stress resistance mechanisms in sesame would help pinpointing important traits for efficient screening of germplasm and facilitate future breeding and genetic improvement studies [25]. Previous studies related to drought research in sesame have applied mainly a moderate stress $[7,9,10,12,13,25-27]$, but in fact, in the semi-arid and arid areas where sesame is commonly grown, drought can last several weeks. Hence, in this study, the response of sesame genotypes for long lasting drought stress was emphasized $[8,11]$. In addition, the originality of the present investigation resides in the fact that (1) it focused on a diverse West and Central African genotypes not yet studied for traits related to drought resistance; and (2) it used an integrated approach by combining agromorphological, physiological, biochemical and seed quality traits to efficiently identify useful genotypes and traits of interest to be targeted for implementing breeding programs in drought-prone environments of West and Central Africa.

\subsection{Drought Avoidance and Tolerance Are Required for Resistance under Severe Water Deficit in Sesame}

Drought seriously affects sesame growth and yield related traits. We uncovered that sesame genotypes like other crops have adapted several survival mechanisms under drought conditions [28]. There are three different mechanisms which help plants to survive under moisture deficit conditions: 1: drought escape; 2: drought avoidance; 3: drought tolerance. Drought avoidance and tolerance are referred to drought resistance [29,30]. One of the first visible signs of water deficit effects on crops is the plant wilting. Leaf wilting level has been proposed in different crops as an index of drought resistance with genotypes exhibiting weak wilting signs likely to be more resistant [31,32]. In this study, although some cultivars had high wilting index scores, they were able to fully recover after rehydration and performed well. The genotype WC08 did not show any wilting sign during the three days of data recording and could be first regarded as a drought resistant genotype. However, the analysis of other traits after recovering from drought stress revealed that WC08 was highly affected as it could not produce enough capsules under stress, slowed down stem and root growth and finally most of the replicated plants died. Most of the genotypes could be attributed to type 1 (drought avoidance) drought resistance mechanism [33]. They maintained relatively high water in tissue through reduced evapo-transpiration surface (leaf area). In rice, it was reported that rolled leaves transpire 41 per cent less water than did the unrolled ones [34] and then help genotypes to better sustain drought. More importantly, the drought resistant genotypes WC17, WC18 and WC14 increased the R/S ratio under drought which is an important indicator of drought avoidance [35]. This is achieved by maintaining the root system development through shoot weight reduction resulting in promoted root absorption. Availability of water thus improves maintenance of cell turgor and support aboveground tissue growth during water stress [35].

Furthermore, analysis of activity levels of antioxidant enzyme as well as proline accumulation in leaves suggested that the drought resistant genotypes also employed type 2 (drought tolerance) of drought resistance mechanisms. Indeed, the antioxidative enzymes are the most efficient mechanisms against oxidative stress caused by water scarcity [18]. The higher activity of SOD, CAT and APX in the drought resistant genotypes indicated that they have stronger ability to remove ROS compared with the sensitive genotypes. Fazeli et al. [36] and Kadkhodaie et al. [37] also concluded that the greater increase of antioxidant enzymes in leaves were related to drought resistance of some sesame genotypes. Furthermore, sesame resistant genotypes had higher proline content in leaves. According to Bohnert and Jensen [38], Ashraf and Foolad [39] and Hayat et al. [40], proline accumulation in plants helps to maintain osmotic balance, stabilizing membranes thereby preventing electrolyte leakage and regulating concentrations of ROS within normal range. Although ROS level in the genotypes was not analyzed in our study, we deduced that the resistant genotypes suffered less from oxidative burst in contrast to the sensitive genotypes. Based on these findings, we propose that both avoidance and tolerance features are crucial for drought resistance under severe drought stress in sesame. Similar conclusions were reported on several important crops including cowpea [41] and wheat [42]. 


\subsection{Does Drought Resistance Maintain Good Seed Quality in Sesame?}

Drought resistance is somehow considered as a penalty towards yield potential [43], even for yield quality. In sesame, previous studies which investigated the effects of drought stress on sesame seed quality concluded that seed components including oil, protein, minerals, fatty acids, antioxidants, sesamin, sesamolin, sesaminol etc., may increase or decrease under water stress depending on the stress duration, growth stage and genotypes $[8,13,44,45]$. We observed that drought globally reduces sesame seed oil content of the five genotypes but the remaining seed components fluctuated according to the genotypes. Similar findings were reported in other important oilseed crops such as canola [46], soybean [47] and safflower [48].

How drought resistant and sensitive sesame genotypes deal with the maintenance of the seed quality under drought stress remained unexplored. Our results suggested that drought resistant genotypes maintain better the seed quality under drought stress compared with the sensitive genotypes. Sesame is essentially grown for its high-quality seed [49]. Hence, sesame genotypes with high ability to provide a good seed quality under stress, are highly desirable.

Nevertheless, it is worth mentioning that in this study, we studied few samples, therefore our conclusions could not be generalized. Additional experiment in large germplasm (with known drought stress level for each genotype) should be implemented to better decipher the link between sesame drought resistance and seed quality maintenance as well as the underlying physiological and biochemical mechanisms.

\subsection{Important Traits for Efficient Screening for Drought Resistance in Sesame}

The identification of a standard evaluation assay has been the most pressing problem for the selection of drought resistant genotypes in crops. In sesame, the lack of efficient selection criteria hampered the development of improved cultivars for drought resistance [6]. Crop resistance to drought is achieved through diverse mechanisms which often work together indicating that different drought related traits must be investigated for an efficient screening of a germplasm [50].

For selecting drought resistant crops, two methods are usually employed including grain yield as direct selection criteria and secondary traits associated with drought [51-53]. In this study, we focused on secondary traits and found that root system traits including PFR, PST, LR and VR exhibited strong correlations with most of the other traits examined, suggesting that root system plays a preponderant role in drought resistance in sesame. Recently, Dossa et al. [54] demonstrated that the maintenance of root morphology and anatomy in a drought tolerant sesame genotype through a strong activity of the antioxidant machinery is essential for endurance under drought stress. Roots have long been proposed as a major avenue of research to improve crop adaptation to water limitations [55]. However, the diversity of root morphology and architecture in sesame has not been examined until now [49]. Therefore, future research may aim at characterizing the diversity of sesame root morphology and architecture as performed in several crops such as pearl millet [56], maize [57], rice [58] and wheat [59]. And then, understanding the relations root morphology and architecture-function—drought resistance in sesame, would effectively guide breeders in exploiting root traits for drought resistance enhancement in sesame.

Root traits may be difficult to be investigated and to be used for a rapid screening in a large panel of sesame genotypes. Hence, non-destructive traits related to water absorption and transpiration such as the stomatal conductance could also be examined in relation to drought resistance in sesame. Based on the strong and positive correlation between root traits and biochemical markers uncovered in this study, we propose that strong accumulation of SOD, CAT, Pr and APX ( $200 \%$ ratio stress/control) could be regarded as an efficient indicator to accurately and rapidly identify drought resistant sesame genotypes. 


\section{Materials and Methods}

\subsection{Plant Materials}

A previous field work of sesame germplasm collection from different producing countries in West and Central Africa was carried out and the materials were preserved at CERAAS (Centre d'Etudes Régional pour l'Amélioration de l'Adaptation à la Sécheresse) in Senegal. A total of 20 genotypes including landraces and improved cultivars harboring a high genetic diversity [24] and representing geographically wide variation was extracted from this collection and used in this study (Table 7). Since the phenology of the genotypes was highly different, only ten genotypes with a similar flowering period (approximately 45 days after sowing) were finally retained for drought stress treatment.

Table 7. Origins and Number of Genotypes Used in This Study.

\begin{tabular}{ccc}
\hline Origin & Number of Genotypes & Number and Code (in Bracket) of Genotypes Kept for Drought Stress \\
\hline Benin & 4 & 2 (WC14, WC17) \\
Burkina Faso & 1 & 1 (WC10) \\
Cameroon & 2 & 1 (WC18) \\
Ivory Coast & 1 & 1 (WC12) \\
Mali & 4 & $3($ WC02, WC03, WC08) \\
Senegal & 3 & 1 (WC06) \\
Togo & 5 & 1 (WC13) \\
Total & 20 & 10 \\
\hline
\end{tabular}

\subsection{Experiment and Stress Treatment}

The experiment was carried out in a greenhouse at the experimental farm of University of Yaounde I, Nkoldongo, ( $3^{\circ} 52^{\prime} 60^{\prime \prime} \mathrm{N}, 11^{\circ} 30^{\prime} 0^{\prime \prime} \mathrm{E} ; 760 \mathrm{~m}$ above sea level) in Cameroon from April to August 2016. Seeds were mixed with calthio $C$ fungicide $(2 \mathrm{~kg} / \mathrm{ha})$ and sown in plastic pots $(25 \mathrm{~cm}$ diameter and $30 \mathrm{~cm}$ depth) filled with $4 \mathrm{~kg}$ of sandy-loam soil with known characteristics. Soil was sterilized before sowing. Pots were maintained to field capacity (FC) and arranged in split plot design with four replicates per genotype. At two true leaves stage, seedlings were thinned to keep two plants per pot. Seedlings were watered normally (every two days) with $500 \mathrm{~mL}$ tap water and $50 \mathrm{~kg} / \mathrm{ha}$ of NPK $(14 / 23 / 14)$ was applied 21 days after sowing (DAS) to ensure good vegetative growth. At beginning of the flowering stage (45 DAS), severe water stress was applied to one group of plants (stressed plants) by withholding irrigation for 21 days and the soil water content decreased to reach approximately $16 \%$ of FC. Then, watering was resumed until full maturation stage (late August). Meanwhile, control plants were well-watered throughout all the experiment. The variation of the mean temperature during stress period is shown in Figure A1.

\subsection{Data Collection}

\subsubsection{Plant Growth and Yield Component Traits}

After two weeks of stress application the leaf wilting index (LWI) was recorded as the ratio of the number of wilted leaves and the total number of leaves on each plant for three days consecutively. At maturity stage, data were collected on each plant of stress and control treatments for stem height $(\mathrm{HP})$, stem fresh weight (PFT), root fresh weight (PFR), stem dry weight (PST), root dry weight (PSR), root volume (VR), length of the primary root (LR), number of capsules per plant (NC), number of seeds per capsule for ten capsules per genotype (Gr) (Table 1).

\subsubsection{Physiological and Biochemical Traits}

All physiological and biochemical traits were determined at the end of the drought stress treatment on stressed and non-stressed plants. The third fully developed leaves from the apex of the plants were collected at 10:30 a.m. Samplings were conducted on each of the two plants per pot for all genotypes 
and samples were frozen in liquid nitrogen before stored at $-80^{\circ} \mathrm{C}$ to preserve the maximum of all components. Fresh leaves were used for leaf relative water content (RWC) detection calculated based on the formula

$$
\mathrm{RWC}(\%)=\frac{(\mathrm{FW}-\mathrm{DW})}{(\mathrm{TW}-\mathrm{DW})} \times 100
$$

where: FW is the fresh weight of the open second leaf, TW is the turgid weight of the second leaf, which was incubated in distilled water for $6 \mathrm{~h}$ in laboratory room temperature, and DW is the dry weight of the leaves after $24 \mathrm{~h}$ in an oven at $60^{\circ} \mathrm{C}$.

Total leaf proline content (Pr) was extracted by the method of Bates et al. [60]. Catalase (CAT), superoxide dismutase (SOD) and ascorbate peroxidase (APX) activities were measured from the extracts prepared as described by Yin et al. [61] and Wei et al. [62] (Table 1).

\subsubsection{Seed Quality Traits}

After harvest, $5 \mathrm{~g}$ of seed samples was collected from five genotypes in both control and stressed plants (the remaining genotypes did not yield enough seeds to perform this analysis). The seed samples were analysed for major seed components such as: oil content (OC), oleic acid $\left(\mathrm{C}_{18: 1}\right)$ content $(\mathrm{OAC})$, linoleic acid $\left(\mathrm{C}_{18: 2}\right)$ content (LAC), protein content (PC), sesamolin content (SC) and sesamin content (SeC) (Table 1). Analyses were performed using a FOSS NIRSystems model 5000 near-infrared reflectance spectroscopy (Foss NIRSystems Inc., Hillerod, Denmark) based on previous works of Liu et al. [63] and Dossa et al. [64]. Each sample was run in triplicate.

\subsection{Data Analysis}

To evaluate the drought resistance of the different genotypes, different drought stress indexes have been calculated according to Wójcik-Jagła et al. [65] using the formula:

$$
r^{\prime \prime} \text { trait }^{\prime \prime}=\frac{\text { value of trait under drought stress }}{\text { value of trait under control condition }} \times 100
$$

The Root to Shoot ratio (R/S) was estimated as the ratio of the root dry weight (PSR) to the shoot dry weight (PST).

All relevant data analysis and graphics were performed using R2.15.2 with the packages "Ade4" [66], "Agricolae" [67], "GrapheR" [68]. In addition, Minitab ${ }^{\circledR} 16$ software (Pennsylvania State University, PA, USA) and MS Excel 2007 (Microsoft, Washington, USA) were also employed. Normal distribution of data was determined using the Shapiro-Wilk W-test, while homogeneity of variances was determined with Bartlett test. ANOVA results were considered significant at $p<0.05$ and mean comparisons were done using Tukey HSD test. The "rcorr" function in the "Hmisc" package [69] was employed for the correlation analysis at significance level $(p<0.05)$ based on Pearson method. The PCA was performed with Minitab ${ }^{\circledR} 16$ (Pennsylvania State University, PA, USA) and the PCA score value was used to rank the drought resistance of each genotype based on the formula described by Liu et al. [70]:

$$
\begin{gathered}
\text { PCA score value }=(\text { contribution of PC1 }(\%) \times \text { PC1 })+(\text { contribution of PC2 }(\%) \times \text { PC2 }) \\
+(\text { contribution of PC3 }(\%) \times \text { PC3 })
\end{gathered}
$$

For the analysis of seed quality traits, the ration stress/control data were submitted to the MEV software [71] and a hierarchical clustering heatmap was constructed.

\section{Conclusions}

In this study, sesame germplasm from West and Central Africa was screened for drought resistance based on agromorphological, physiological and biochemical traits. The genotypes WC17, WC14 and WC18 were the most resistant to drought. They displayed both drought avoidance and tolerance 
features including morphological, physiological and biochemical changes leading to drought resistance. In addition, they maintained higher seed quality after drought stress compared with the sensitive genotypes. The biochemical traits including SOD, APX, CAT and Pr could be prioritized when screening large germplasm for drought resistance. In addition, our results suggested that root traits may play a preponderant role in sesame drought resistance. Future studies may rely on these results to further drought stress investigations in aim of releasing highly drought resistant genotypes for the benefit of local farmers in West and Central Africa.

Acknowledgments: This work was financially supported by the grants offered by the intra-ACP program "PAFROID" to the first two authors. The first author thanks the DAAD for providing scholarship. We are grateful to Awa Sy, Lailat Kassim, Hodo-Abalo Tossim and Romaric J. Nguepjop for their assistance during data collection. We also extend our sincere appreciation to all colleagues who helped during sesame germplasm collection in West and Central African countries.

Author Contributions: For research articles with several authors, a short paragraph specifying their individual contributions must be provided. The following statements should be used D.D., B.L., X.Z., N.C. and J.M.B. conceived and designed the experiments; K.D., L.W.Y. and B.C.L.-L.-N. performed the experiments; K.D., B.L., B.C.L.-L.-N. and D.D. analyzed the data; X.Z., N.C. and J.M.B. contributed reagents/materials/analysis tools; K.D., D.D. and B.L. wrote the paper.

Conflicts of Interest: The authors declare no conflict of interest.

\section{Appendix A}

\section{$\mathrm{T}\left(\mathrm{C}^{\circ}\right)$}

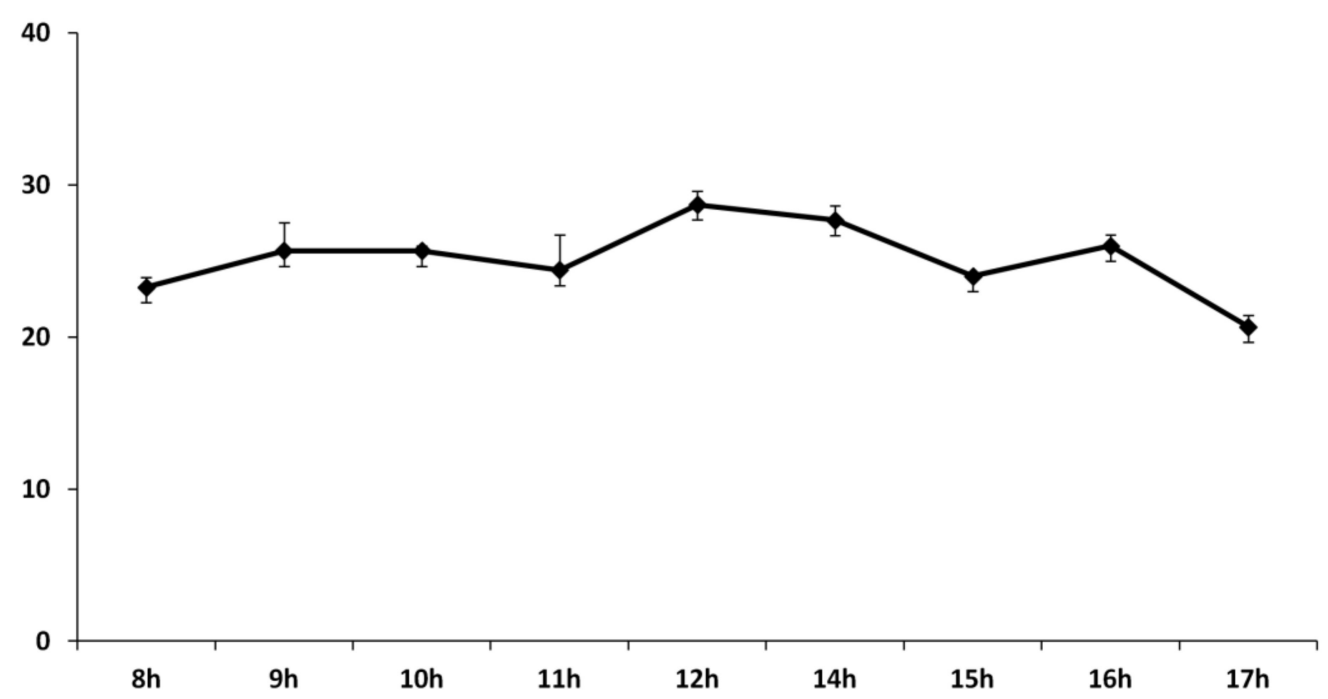

Figure A1. Variation of the Mean Temperature during Stress Treatment.

\section{References}

1. Uzun, B.; Arslan, C.; Furat, S. Variation in fatty acid compositions, oil content and oil yield in germplasm collection of sesame (Sesamum indicum L.). J. Am. Oil Chem. Soc. 2008, 85, 1135-1142. [CrossRef]

2. Faostat. Food and Agriculture Organization Statistical Databases 2015. Available online: http://faostat.fao. org/ (accessed on 12 December 2016).

3. Gildemacher, P.; Audet-Bélanger, G.; Mangnus, E.; Van de Pol, F.; Tiombiano, D.; Sanogo, K. Sesame Sector Development; Lessons Learned in Burkina Faso and Mali; KIT \& CFC: Amsterdam, The Netherlands, 2015; Available online: https:/ / commonfunds.sharepoint.com/Projects/FIGOOF/FIGOOF-27/1\%20Sesame\% 20Sector\%20Development.pdf (accessed on 16 March 2017). 
4. Langham, D.R. Phenology of sesame. In Issues in New Crops and New Uses; Janick, J., Whipkey, A., Eds.; ASHS Press: Alexandria, VA, USA, 2007; pp. 144-182.

5. Dossa, K.; Konteye, M.; Niang, M.; Doumbia, Y.; Cissé, N. Enhancing sesame production in West Africa's Sahel: A comprehensive insight into the cultivation of this untapped crop in Senegal and Mali. Agric. Food Secur. 2017, in press.

6. Boureima, S.; Diouf, M.; Amoukou, A.I.; Damme, V.P. Screening for sources of tolerance to drought in sesame induced mutants: Assessment of indirect selection criteria for seed yield. Int. J. Pure Appl. Biosci. 2016, 4, 45-60. [CrossRef]

7. Betram, K.; Janssens, M.J.J.; Abdalwahab, A. Breeding for drought tolerance in sesame (Sesamum indicum). In Proceedings of the Conference on Technological and Institutional Innovations for Sustainable Rural Development, Deutscher Tropentag, Gottingen, Germany, 8-10 October 2003; p. 135.

8. Kim, K.S.; Park, S.H.; Jenks, M.A. Changes in leaf cuticular waxes of sesame (Sesamum indicum L.) plants exposed to water deficit. J. Plant Physiol. 2006, 164, 1134-1143. [CrossRef] [PubMed]

9. Hassanzadeh, M.; Asghari, A.; Jamaati-e-Somarin, S.; Saeidi, M.; Zabihi-e-Mahmoodabad, R.; Hokmalipour, S. Effects of water deficit on drought tolerance indices of sesame (Sesamum indicum L.) genotypes in moghan region. Res. J. Environ. Sci. 2009, 3, 116-121. [CrossRef]

10. Bahrami, H.; Razmjoo, J.; Jafari, A.O. Effect of drought stress on germination and seedling growth of sesame cultivars (Sesamum indicum L.). Int. J. Agric. Sci. 2012, 2, 423-428.

11. Boureima, S.; Oukarroum, A.; Diouf, M.; Cissé, N.; Van Damme, P. Screening for drought tolerance in mutant germplasm of sesame (Sesamum indicum) probing by chlorophyll a fluorescence. Environ. Exp. Bot. 2012, 81, 37-43. [CrossRef]

12. Kadkhodaie, A.; Razmjoo, J.; Zahedi, M.; Pessarakli, M. Selecting sesame genotypes for drought tolerance based on some physiochemical traits. Agron. J. 2014, 106, 111-118. [CrossRef]

13. Kadkhodaie, A.; Razmjoo, J.; Zahedi, M.; Pessarakli, M. Oil content and composition of sesame (Sesamum indicum L.) genotypes as affected by irrigation regimes. J. Am. Oil Chem. Soc. 2014, 91, 1737-1744. [CrossRef]

14. Pathak, N.; Rai, A.K.; Kumari, R.; Thapa, A.; Bhat, K.V. Sesame crop: An underexploited oilseed holds tremendous potential for enhanced food value. Agric. Sci. 2014, 5, 519-529. [CrossRef]

15. Farooq, M.; Hussain, M.; Wahid, A.; Siddique, K.H.M. Drought stress in plants: An overview. In Plant Responses to Drought Stress: From Morphological to Molecular Features; Aroca, R., Ed.; Springer: Berlin/Heidelberg, Germany, 2012; pp. 1-33.

16. Bänziger, M.; Lafitte, H.R. Efficiency of secondary traits for improving maize for low-nitrogen target environments. Crop Sci. 1997, 37, 1110-1117. [CrossRef]

17. Lata, C.; Yadav, A.; Prasad, M. Role of plant transcription factors in abiotic stress tolerance. In Abiotic Stress Response in Plants-Physiological, Biochemical and Genetic Perspectives; Shanker, A., Ed.; InTech: London, UK, 2011; ISBN 978-953-307-672-0. Available online: http:/ / www.intechopen.com/books/abiotic-stressresponse-in-plants-physiological-biochemical-and-genetic-perspectives / role-of-plant-transcriptionfactors-in-abiotic-stress-tolerance (accessed on 2 June 2017).

18. Farooq, M.; Basra, S.M.A.; Wahid, A.; Cheema, Z.A.; Cheema, M.A.; Khaliq, A. Physiological role of exogenously applied glycinebetaine to improve drought tolerance in fine grain aromatic rice (Oryza sativa L.). J. Agron. Crop Sci. 2008, 194, 325-333. [CrossRef]

19. Yordanova, R.Y.; Alexieva, V.S.; Popova, L.P. Influence of root oxygen deficiency on photosynthesis and antioxidant status in barley plants. Russ. J. Plant Physiol. 2003, 50, 163-167. [CrossRef]

20. Sergi, M.; Alegre, L. Drought-induced changes in redox state of $\alpha$-tocopherol, ascorbate and the diterpene carnosic acid in chloroplasts of Labiatae species differing in carnosic acid contents. Plant Physiol. 2003, 131, 1816-1825.

21. Agarwal, S.; Pandey, V. Antioxidant enzyme responses to $\mathrm{NaCl}$ stress in Cassia angustifolia. Biol. Plant. 2004, 48, 555-560. [CrossRef]

22. Pinhero, R.G.; Pao, M.V.; Palyath, G.; Murr, D.P.; Fletcher, R.A. Changes in the activities of antioxidant enzymes and their relationship to genetic and paclobutrazol induced chilling tolerance of maize seedlings. J. Plant Physiol. 2000, 114, 695-704. [CrossRef]

23. Mittler, R. Oxidative stress, antioxidants and stress tolerance. Trends Plant Sci. 2002, 7, 405-410. [CrossRef] 
24. Dossa, K.; Wei, X.; Li, D.; Zhang, Y.; Fonceka, D.; Yang, W.; Diouf, D.; Cissé, N.; Liao, B.; Zhang, X. Analysis of genetic diversity and population structure of sesame accessions from Africa and Asia as major centers of its cultivation. Genes 2016, 7, 14. [CrossRef] [PubMed]

25. Dossa, K.; Niang, M.; Assogbadjo, A.E.; Cissé, N.; Diouf, D. Whole genome homology-based identification of candidate genes for drought tolerance in sesame (Sesamum indicum L.). Afr. J. Biotechnol. 2016, 15, 1464-1475.

26. Dossa, K.; Wei, X.; Li, D.; Zhang, Y.; Wang, L.; Fonceka, D.; Yu, J.; Diouf, D.; Liao, B.; Cissé, N.; et al. Insight into the AP2/ERF transcription factor superfamily in sesame (Sesamum indicum) and expression profiling of the DREB subfamily under drought stress. BMC Plant Biol. 2016, 16, 171. [CrossRef] [PubMed]

27. Dossa, K.; Diouf, D.; Cissé, N. Genome-wide investigation of Hsf genes in sesame reveals their segmental duplication expansion and their active role in drought stress response. Front. Plant Sci. 2016, 7, 1522. [CrossRef] [PubMed]

28. De Santos, I.C.; de Almeida, A.A.F.; Anhert, D.; de Conceiçao, A.S.; Pirovani, C.P.; Pires, J.L.; Valle, R.R.; Baligar, V.C. Molecular, physiological and biochemical responses of Theobroma cacao L. genotypes to soil water deficit. PLoS ONE 2014, 9, e115746. [CrossRef] [PubMed]

29. Xu, Z.; Zhou, G.; Shimizu, H. Plant responses to drought and rewatering. Plant Signal. Behav. 2010, 5, 649-654. [CrossRef] [PubMed]

30. Singh, S.; Pradhan, S.; Singh, A.; Singh, O. Marker validation in recombinant inbred lines and random varieties of rice for drought tolerance. Aust. J. Crop Sci. 2012, 6, 606-612.

31. Subashri, M.; Robin, S.; Vinod, K.K.; Rajeswari, S.; Mohanasundaram, K.; Raveendran, T.S. Trait identification and QTL validation for reproductive stage drought resistance in rice using selective genotyping of near flowering RILs. Euphytica 2008, 166, 291-305. [CrossRef]

32. Salunkhe, A.S.; Poornima, R.; Prince, K.S.J.; Kanagaraj, P.; Sheeba, J.A.; Amudha, K.; Suji, K.K.; Senthil, A.; Babu, R.C. Fine mapping QTL for drought resistance traits in rice (Oryza sativa L.) using bulk segregant analysis. Mol. Biotechnol. 2011, 49, 90-95. [CrossRef] [PubMed]

33. Mitra, J. Genetics and genetic improvement of drought resistance in crop plants. Curr. Sci. 2001, 80, 758-763.

34. Courtois, B.; McLaren, G.; Sinha, P.K.; Prasad, K.; Yadav, R.; Shen, L. Mapping QTLs associated with drought avoidance in upland rice. Mol. Breed. 2000, 6, 55-66. [CrossRef]

35. Tatrai, Z.A.; Sanoubar, R.; Pluhar, Z.; Mancarella, S.; Orsini, F.; Gianquinto, G. Morphological and physiological plant responses to drought stress in Thymus citriodorus. Int. J. Agron. 2016, 2016, 14165750. [CrossRef]

36. Fazeli, F.; Ghorbanli, M.; Niknam, V. Effect of drought on biomass, protein content, lipid peroxidation and antioxidant enzymes in two sesame cultivars. Biol. Plant. 2007, 51, 98-103. [CrossRef]

37. Kadkhodaie, A.; Zahedi, M.; Razmjoo, J.; Pessarakli, M. Changes in some anti-oxidative enzymes and physiological indices among sesame genotypes (Sesamum indicum L.) in response to soil water deficits under field conditions. Acta Physiol. Plant. 2013, 36, 641-650. [CrossRef]

38. Bohnert, H.J.; Jensen, R.G. Strategies for engineering water-stress tolerance in plants. Trends Biotechnol. 1996, 14, 89-97. [CrossRef]

39. Ashraf, M.; Foolad, M.R. Roles of glycine betaine and proline in improving plant abiotic stress resistance. Environ. Exp. Bot. 2007, 59, 206-216. [CrossRef]

40. Hayat, S.; Hayat, Q.; Alyemeni, M.N.; Wani, A.S.; Pichtel, J.; Ahmad, A. Role of proline under changing environments. Plant Signal. Behav. 2012, 11, 1456-1466. [CrossRef] [PubMed]

41. Agbicodo, E.M.; Fatokun, C.A.; Muranaka, S.; Visser, R.G.F. Breeding drought tolerant cowpea: Constraints, accomplishments, and future prospects. Euphytica 2009, 167, 353-370. [CrossRef]

42. Nezhadahmadi, A.; Prodhan, Z.H.; Faruq, G. Drought tolerance in wheat. Sci. World J. 2013, $2013,610721$. [CrossRef] [PubMed]

43. Blum, A. Drought resistance, water-use efficiency, and yield potential-Are they compatible, dissonant, or mutually exclusive? Aust. J. Agric. Res. 2005, 56, 1159-1168. [CrossRef]

44. Eskandari, H.; Zehtabsalmasi, S.; Ghassemigolezani, K.; Gharineh, M.H. Effects of water limitation on grain and oil yields of sesame cultivars. J. Food Agric. Environ. 2009, 7, 339-342.

45. Ozkan, A.; Kulak, M. Effects of water stress on growth, oil yield, fatty acid composition and mineral content of Sesamum indicum. J. Anim. Plant Sci. 2013, 23, 1686-1690.

46. Aslam, M.N.; Nelson, M.N.; Kailis, S.G.; Bayliss, K.L.; Speijers, J.; Cowling, W.A. Canola oil increases in polyunsaturated fatty acids and decreases in oleic acid in drought-stressed Mediterranean type environments. Plant Breed. 2009, 128, 348-355. [CrossRef] 
47. Dornbos, D.L.; Mullen, R.E. Soybean seed protein and oil contents and fatty acid composition adjustments by drought and temperature. J. Am. Oil Chem. Soc. 1992, 69, 228-231. [CrossRef]

48. Ashrafi, E.O.; Razmjoo, K.O. Effect of irrigation regimes on oil content and composition of safflower (Carthamus tinctorius L.) cultivars. J. Am. Oil Chem. Soc. 2010, 87, 499-506. [CrossRef]

49. Dossa, K.; Diouf, D.; Wang, L.; Wei, X.; Zhang, Y.; Niang, M.; Fonceka, D.; Yu, J.; Mmadi, A.M.; Yehouessi, L.W.; et al. The emerging oilseed crop Sesamum indicum enters the "Omics" era. Front. Plant Sci. 2017, 8, 1154. [CrossRef] [PubMed]

50. Rosales-Serna, R.; Ramírez-Vallejo, P.; Acosta-Gallegos, J.A.; Castillo-González, F.; Kelly, J.D. Grain yield and drought tolerance of common bean under field conditions. Agrociencia 2000, 34, 153-165.

51. Rosielle, A.A.; Hamblin, J. Theoretical aspects of selection for yield in stress and non-stress environment. Crop Sci. 1981, 21, 943-946. [CrossRef]

52. Teran, H.; Singh, S.P. Comparison of sources and lines selected for drought resistance in common bean. Crop Sci. 2002, 42, 64-70. [CrossRef] [PubMed]

53. Lafitte, R.; Blum, A.; Atlin, G. Using secondary traits to help identify drought-tolerant genotypes. In Breeding Rice for Drought-Prone Environments; Fischer, K.S., Lafitte, R., Fukai, S., Atlin, G., Hardy, B., Eds.; International Rice Research Institute: Los Banos, PH, USA, 2003; pp. 37-61.

54. Dossa, K.; Li, D.; Wang, L.; Zheng, X.; Liu, A.; Yu, J.; Wei, X.; Zhou, R.; Fonceka, D.; Diouf, D.; et al. Transcriptomic, biochemical and physio-anatomical investigations shed more light on responses to drought stress in two contrasting sesame genotypes. Sci. Rep. 2017, 7, 8755. [CrossRef] [PubMed]

55. Vadez, V. Root hydraulics: The forgotten side of roots in drought adaptation. Field Crop. Res. 2014, 165, 15-24. [CrossRef]

56. Passot, S.; Gnacko, F.; Moukouanga, D.; Lucas, M.; Guyomarc'h, S.; Ortega, M.B.; Atkinson, J.A.; Belko, M.N.; Bennett, M.J.; Gantet, P.; et al. Characterization of pearl millet root architecture and anatomy reveals three types of lateral roots. Front. Plant Sci. 2016, 7, 829. [CrossRef] [PubMed]

57. Amato, M.; Ritchie, J.T. Spatial distribution of roots and water uptake of maize (Zea mays L.) as affected by soil structure. Crop Sci. 2002, 42, 773-780. [CrossRef]

58. Henry, A.; Gowda, V.R.P.; Torres, R.O.; McNally, K.L.; Serraj, R. Variation in root system architecture and drought response in rice (Oryza sativa): Phenotyping of the OryzaSNP panel in rainfed lowland fields. Field Crop. Res. 2011, 120, 205-214. [CrossRef]

59. Liao, M.T.; Palta, J.A.; Fillery, I.R.P. Root characteristics of vigorous wheat improve early nitrogen uptake. Aust. J. Agric. Res. 2006, 57, 1097-1107. [CrossRef]

60. Bates, L.S.; Waldren, R.P.; Teare, I.D. Rapid determination of free proline for water stress studies. Plant Soil 1973, 39, 205-207. [CrossRef]

61. Yin, D.M.; Chen, S.M.; Chen, F.D.; Guan, Z.Y.; Fang, W.M. Morpho-anatomical and physiological responses of two Dendranthema species to waterlogging. Environ. Exp. Bot. 2010, 68, 122-130. [CrossRef]

62. Wei, W.; Li, D.; Wang, L.; Ding, X.; Zhang, Y.; Gao, Y.; Zhang, X. Morpho-anatomical and physiological responses to waterlogging of sesame (Sesamum indicum L.). Plant Sci. 2013, 208, 102-111. [CrossRef] [PubMed]

63. Liu, P.; Zhang, Y.; Li, D.; Wang, L.; Gao, Y.; Zhou, R.; Zhang, X.; Wei, X. Establishment of near infrared reflectance spectroscopy model for sesame oil and protein content detection and variation analysis of the core collection of sesame (Sesamum indicum L.). Chin. J. Oil Crop Sci. 2016, 38, 722-729.

64. Dossa, K.; Wei, X.; Niang, M.; Liu, P.; Zhang, Y.; Wang, L.; Liao, B.; Cissé, N.; Zhang, X.; Diouf, D. Near-infrared reflectance spectroscopy reveals wide variation in major components of sesame seeds from Africa and Asia. Crop J. 2017, in press. [CrossRef]

65. Wójcik-Jagła, M.; Rapacz, M.; Tyrka, M.; Kościelniak, J.; Crissy, K.; Żmuda, K. Comparative QTL analysis of early short-time drought tolerance in Polish fodder and malting spring barleys. Theor. Appl. Genet. 2013, 126, 3021-3034. [CrossRef] [PubMed]

66. Dray, S.; Dufour, A.; Leeuw, J.D.; Zeileis, A. The ade4 Package: Implementing the duality diagram for ecologists. J. Stat. Softw. 2007, 22, 1-20. [CrossRef]

67. De Mendiburu, F. Agricolae: Statistical procedures for agricultural research. $R$ Package 2014, 1, 1-16.

68. Hervé, M. GrapheR: A Multiplatform GUI for drawing customizable graphs in R. R J. 2011, 3, $99-103$.

69. Harell, F.E., Jr. The Hmisc Package. R Package 2006, 3, 12. 
70. Liu, Y.; Zhang, X.; Tran, H.; Shan, L.; Kim, J.; Childs, K.; Ervin, E.H.; Frazier, T.; Zhao, B. Assessment of drought tolerance of 49 switchgrass (Panicum virgatum) genotypes using physiological and morphological parameters. Biotechnol. Biofuels 2015, 8, 152. [CrossRef] [PubMed]

71. Saeed, A.I.; Sharov, V.; White, J.; Li, J.; Liang, W.; Bhagabati, N.; Braisted, J.; Klapa, M.; Currier, T.; Thiagarajan, M.; et al. TM4: A free, open-source system for microarray data management and analysis. Biotechniques 2003, 34, 374-378. [PubMed]

(c) (C) 2017 by the authors. Licensee MDPI, Basel, Switzerland. This article is an open access article distributed under the terms and conditions of the Creative Commons Attribution (CC BY) license (http:/ / creativecommons.org/licenses/by/4.0/). 